\title{
STRONY POSTĘPOWANIA W ŚWIETLE PRZEPISÓW USTAWY Z DNIA 7 LIPCA 1994 R. PRAWO BUDOWLANE
}

\begin{abstract}
Streszczenie. Przedmiotem artykułu są prawne problemy dotyczące strony postępowania prawa budowlanego w świetle ustawy z dnia 7 lipca $1994 \mathrm{r}$. Analizowane zagadnienie ma doniosłe znaczenie ze względu na stosowanie prawa przez sądy i organy administracji. Celem niniejszego artykułu jest również zaprezentowanie podstawowych problemów prawnych związanych z wykładnią pojęcia strony postepowania w prawie budowlanym w praktycznym wymiarze.
\end{abstract}

Słowa kluczowe: strona postępowania, prawo budowlane, pozwolenie na budowę, definicja.


wiązanie polegające na zawarciu w tym akcie prawnym czterech ustawowych definicji strony postępowania. Analiza przepisów, które opisują treść tych definicji, wskazuje, że celem ich wprowadzenia było ograniczenie liczby podmiotów, które mogą uczestniczyć w postępowaniu w charakterze strony.

Definicje te wskazane są w art. 28 ust. 2 ww. ustawy (wydanie pozwolenia na budowę), art. 40 ust. 3 (przeniesienie pozwolenia na budowę oraz pozwolenia na wznowienie robót budowlanych), art. 40 ust. 3 (przeniesienie uprawnień wynikających ze zgłoszenia budowy lub robót budowlanych) oraz w art. 59 ust. 7 tejże ustawy (pozwolenie na użytkowanie).

Jednym z zasadniczych celów ustawy Prawo budowlane jest regulacja zagadnień związanych $\mathrm{z}$ wydawaniem pozwoleń na budowę. $\mathrm{W}$ odniesieniu do tych postępowań ustawodawca zdecydował się na stworzenie autonomicznej definicji strony postępowania. Zgodnie z treścią art. 28 ust. 2 ustawy Prawo budowlane stronami w postępowaniu w sprawie pozwolenia na budowę są: inwestor oraz właściciele, użytkownicy wieczyści lub zarządcy nieruchomości znajdujących się w obszarze oddziaływania obiektu.

Nieruchomością zgodnie z treścią art. 46 § 1 k.c. będzie część powierzchni ziemskiej stanowiąca odrębny przedmiot własności (grunty), jak również budynki trwale z gruntem związane lub części takich budynków, jeżeli na mocy przepisów szczególnych stanowią odrębny od gruntu przedmiot własności.

W ustawie Prawo budowlane brak definicji ustawowej inwestora, stąd też treść tego pojęcia musi być ustalona w drodze wykładni. W słownikowym znaczeniu

\footnotetext{
*Sędzia Naczelnego Sądu Administracyjnego, gczerwin@interia.pl

${ }^{1}$ Dz. U. 2013, poz. 1409 j.t. ze zm.
} 
pojęcia inwestor to „osoba lub przedsiębiorca dokonujący inwestycji”, zaś inwestycja to „przeznaczenie środków finansowych na powiększenie lub odtworzenie zasobów majątkowych" (Dubisz 2003, 1239). Wykładnia tego pojęcia jest też przedmiotem rozważań w piśmiennictwie prawniczym. Jerzy Siegień uważa, że mając na uwadze zakres obowiązków określonych w art. 18 ust. 1 ustawy Prawo budowlane, przyjąć należy, że inwestorem jest osoba fizyczna, osoba prawna albo jednostka organizacyjna nieposiadająca osobowości prawnej ponosząca nakłady finansowe na budowę i organizująca proces tej budowy. Inwestor nie musi być przyszłym właścicielem realizowanego obiektu budowlanego. Może to być podmiot, który buduje na przykład domy jednorodzinne w celu ich późniejszej sprzedaży zainteresowanym osobom (Siegień 2003, 179). Krzysztof Radzikowski natomiast uważa, że inwestorem jest podmiot, który działając we własnym imieniu i na własny rachunek, ponosi ekonomiczny ciężar oraz organizuje proces budowlany w celu czerpania w przyszłości korzyści gospodarczych z ukończonej inwestycji (Radzikowski 2005).

Inwestorem może być osoba, która nie posiada żadnego tytułu do dysponowania nieruchomością na cele budowlane. Brak takiego tytułu może być jedynie podstawą odmowy wydania pozwolenia na budowę, nie może natomiast być podstawą odmowy uznania takiego podmiotu za stronę postępowania.

Właściciel nieruchomości to podmiot, któremu przysługują uprawnienia wymienione $\mathrm{w}$ art. 140 k.c. $\mathrm{w}$ granicach określonych tym przepisem. Z kolei użytkownikiem wieczystym nieruchomości będzie podmiot, któremu przysługują uprawnienia określone w art. 233 k.c. również w granicach określonych tym przepisem.

Ostatnim z podmiotów, który wymieniony został w art. 28 ust. 2 ustawy Prawo budowlane, jest zarządca nieruchomości. Zarządca nieruchomości w świetle przepisów tej ustawy ma pozycję samodzielną. Nie jest reprezentantem strony postępowania, tylko samodzielną stroną.

Pojęcie „zarządca nieruchomości” nie zostało zdefiniowane w ww. ustawie. W znaczeniu słownikowym „zarządca” to „ten, kto zarządza czymś, administrator”, zaś ,zarządzać” oznacza „sprawować nad czymś zarząd, kierować czymś” (Dubisz 2003, 874)

W literaturze prawniczej pojęcie „zarząd” używane jest zarówno na określenie ogółu czynności składających się na administrowanie rzeczą czy majątkiem, jak i na oznaczenie pewnej formy organizacyjnej sprawowania władzy wykonawczej (np. zarząd spółki z o.o.), dokonywanie czynności dla innej osoby i na jej rzecz. W pojęciu zarządzania mieści się także pojęcie ,administrowania”, które ma węższy charakter. Obejmuje ono w zasadzie wyłącznie czynności faktyczne, takie jak: utrzymanie porządku i czystości w obrębie nieruchomości, rejestrowanie właścicieli lub najemców nieruchomości, ściąganie czynszów, rejestrowanie awarii oraz ich usuwanie, organizowanie spotkań współwłaścicieli, prowadzenie korespondencji (Bieniek, Kalus, Marmaj, Mzyk 2005, 230-231). 
Definicję ustawową ,zarządcy nieruchomości” zawiera ustawa z 21 sierpnia 1997 r. o gospodarce nieruchomościami². Art. 184 tej ustawy stanowi, że zarządzanie nieruchomościami jest działalnością zawodową wykonywaną przez zarządców nieruchomości na zasadach określonych w tejże ustawie. $Z$ kolei zarządcą nieruchomości jest osoba fizyczna posiadająca licencję zawodową nadaną w trybie przepisów rozdziału 4 tejże ustawy. Zarządzanie nieruchomością polega na podejmowaniu decyzji i dokonywaniu czynności mających na celu zapewnienie właściwej gospodarki ekonomiczno-finansowej nieruchomości oraz zapewnienie bezpieczeństwa użytkowania i właściwej eksploatacji nieruchomości, w tym bieżącego administrowania nieruchomością, jak również czynności zmierzających do utrzymania nieruchomości w stanie niepogorszonym zgodnie z jej przeznaczeniem oraz do uzasadnionego inwestowania w tę nieruchomość (art.185).

Pojęcie ,zarząd” występuje też w wielu innych aktach prawnych. W art. 200 k.c. mowa jest o tym, że każdy ze współwłaścicieli jest obowiązany do współdziałania w zarządzaniu rzeczą wspólną. W przepisach k.c. pojęcie zarządu nie zostało zdefiniowane. W literaturze prezentowany jest pogląd, że jest to ogół działań podejmowanych przez podmiot $\mathrm{w}$ określonym celu. Będą to poszczególne zachowania podejmowane przez uprawnione podmioty, które odnoszą się do składników majątku należących z reguły do innych osób (Uliasz 2002, 825). $\mathrm{Z}$ art. 611-616 k.p.c. wynika, że zarządca sądowy obowiązany jest do wykonywania czynności potrzebnych do prawidłowej gospodarki rzeczą (art. 615 k.p.c.) oraz uprawniony jest do pobierania z niej dochodów, a po pokryciu wydatków wypłaca pozostałym współwłaścicielom nadwyżkę (art. 613 k.p.c.). W sprawach wynikających z zarządu zarządca może pozywać i być pozwany (art. 934 k.p.c. i art. 935 k.p.c. w zw. z art. 612, 613 i 615 k.p.c.).

Dokonując oceny, czy dany podmiot może być uznany za zarządcę nieruchomości w rozumieniu art. 28 ust. 2 ustawy Prawo budowlane, ustalić należy, czy podmiot ten jest upoważniony przez właściciela lub użytkownika wieczystego do podejmowania czynności faktycznych i prawnych w odniesieniu do tej nieruchomości. Bez spełnienia tych wymogów podmiot taki może być uznany co najwyżej za administratora nieruchomości.

Dla ustalenia, czy dany podmiot jest stroną postępowania o wydanie pozwolenia na budowę, nie wystarczy stwierdzenie, że podmiot ten jest właścicielem, użytkownikiem wieczystym lub zarządcą nieruchomości. Konieczne jest również ustalenie, że nieruchomość ta znajduje się w obszarze oddziaływania obiektu, który ma być zrealizowany. W art. 3 pkt 20 ustawy Prawo budowlane zawarta została ustawowa definicja tego obszaru. Przepis ten stanowi, że przez obszar oddziaływania obiektu należy rozumieć teren wyznaczony w otoczeniu obiektu budowlanego na podstawie przepisów odrębnych, wprowadzających związane $\mathrm{z}$ tym obiektem ograniczenia $\mathrm{w}$ zagospodarowaniu, w tym zabudowy tego terenu.

\footnotetext{
${ }^{2}$ Dz. U. 1997, Nr 115, poz. 741 ze zm.
} 
Nie jest to definicja wyczerpująca, albowiem nie wskazano w niej „przepisów odrębnych", które należy brać pod uwagę przy wyznaczaniu obszaru oddziaływania. Może to więc być każdy przepis, który w związku z realizacją obiektu skutkuje powstaniem ograniczeń w korzystaniu z innej nieruchomości niż ta, na której obiekt ten ma być posadowiony. Przykładem tego rodzaju przepisu może być $§ 20$ rozporządzenia Ministra Obrony Narodowej z 4 października 2001 r. w sprawie warunków technicznych, jakim powinny odpowiadać strzelnice garnizonowe oraz ich usytuowanie ${ }^{3}$, który stanowi, że wyznacza się strefy ochronne dla każdej strzelnicy garnizonowej. Zgodnie zaś z § 22 ust. 1 tego rozporządzenia w strefach ochronnych strzelnicy garnizonowej nie mogą znajdować się obiekty i pomieszczenia przeznaczone na stały lub czasowy pobyt ludzi, w rozumieniu przepisów określających warunki techniczne, jakim powinny odpowiadać budynki i ich usytuowanie. Budowa strzelnicy dla właściciela, użytkownika wieczystego lub zarządcy nieruchomości znajdującej się w takiej strefie skutkowałaby niemożnością realizacji budynku mieszkalnego. Możliwości zagospodarowania takiej nieruchomości byłyby więc ograniczone.

Przykładem przepisu, który w związku z realizacją obiektu budowlanego może ograniczać możliwość zagospodarowania nieruchomości, może też być $§ 9$ ust. 3 rozporządzenia Ministra Gospodarki z 30 lipca 2001 r. w sprawie warunków technicznych, jakim powinny odpowiadać sieci gazowe ${ }^{4} . Z \S 9$ ust. 4 tego rozporządzenia wynika, że w strefach kontrolowanych nie należy wznosić budynków, urządzać stałych składów i magazynów, sadzić drzew oraz nie powinna tam być podejmowana żadna działalność mogąca zagrozić trwałości gazociągu podczas jego eksploatacji. Strefa kontrolowana zaś to, zgodnie z $§ 2$ pkt 5 ww. rozporządzenia, obszar wyznaczony po obu stronach osi gazociagu, w którym operator sieci gazowej podejmuje czynności w celu zapobieżenia działalności mogącej mieć negatywny wpływ na trwałość i prawidłową eksploatację gazociagu.

W art. 3 pkt 20 ustawy Prawo budowlane ustawodawca posłużył się sformułowaniem ,przepisy odrębne”. Istotne dla ustalenia obszaru oddziaływania obiektu jest rozstrzygnięcie zagadnienia, czy za przepisy odrębne uznać należy przepisy rozporządzeń wykonawczych wydanych na podstawie przepisów ustawy Prawo budowlane. Wiele ograniczeń $\mathrm{w}$ możliwości zagospodarowania nieruchomości sąsiadujących bezpośrednio lub pośrednio z nieruchomością, na której realizowana ma być inwestycja, wynika z rozporządzeń określających warunki techniczne realizacji różnego rodzaju obiektów budowlanych. W piśmiennictwie przyjmuje się, że przepisy rozporządzeń wykonawczych do ustawy Prawo budowlane zalicza się do przepisów odrębnych (Dźwiński, Ziemski, 2005, 28-30). Pogląd ten należy w pełni podzielić. Wykładnia celowościowa art. 2 pkt 20 ustawy Prawo budowlane przemawia za tym, by przepisy rozporządzeń wykonawczych do tej

\footnotetext{
${ }^{3}$ Dz. U. Nr 132, poz. 1479.

${ }^{4}$ Dz. U. 2001, Nr 97, poz. 1055.
} 
ustawy były traktowane jako przepisy odrębne. Nie ma bowiem uzasadnionych podstaw do wyłączenia ograniczeń w zagospodarowaniu nieruchomości wynikających z tych przepisów do ustalania obszaru jego oddziaływania.

Przy ustalaniu obszaru oddziaływania obiektu należy mieć też na uwadze, że w pewnych przypadkach ustawodawca wprost przesądził o tym, że określone nieruchomości uznać należy za nieruchomości znajdujące się w tego rodzaju obszarze. Z $\S 12$ ust. 4 rozporządzenia Ministra Infrastruktury z 12 kwietnia 2002 r. w sprawie warunków technicznych, jakim powinny odpowiadać budynki i ich usytuowanie ${ }^{5}$, wynika, że usytuowanie budynku na działce budowlanej w sposób, o którym mowa w ust. 2 i 3, powoduje objęcie sąsiedniej działki budowlanej obszarem oddziaływania w rozumieniu art. 3 pkt 20 ustawy z 7 lipca 1994 r. Prawo budowlane. Usytuowanie, o którym mowa w $\S 2$ i 3 tego rozporządzenia, to usytuowanie będące odstępstwem od zasady, że budynek na działce budowlanej należy sytuować w odległości od granicy z sąsiednią działką budowlaną nie mniejszej niż $4 \mathrm{~m}-\mathrm{w}$ przypadku budynku zwróconego ścianą z otworami okiennymi lub drzwiowymi w stronę tej granicy, oraz nie mniejszej niż $3 \mathrm{~m}$ - w przypadku budynku zwróconego ścianą bez otworów okiennych lub drzwiowych w stronę tej granicy.

Zwrócić należy uwagę na okoliczność, że definicja wskazana w § 12 ust. 4 ww. rozporządzenia odnosi się do działki budowlanej oraz budynku. W ustawie Prawo budowlane nie ma definicji „działki budowlanej”, jednakże definicja taka znajduje się w ustawie z 27 marca 2003 r. o planowaniu i zagospodarowaniu przestrzennym ${ }^{6}$, która to ustawa reguluje zagadnienia związane $\mathrm{z}$ etapem poprzedzającym wydanie pozwolenia na budowę. Z art. 2 pkt 12 tej ustawy wynika, że przez „działkę” budowlaną należy rozumieć nieruchomość gruntową lub działkę gruntu, której wielkość, cechy geometryczne, dostęp do drogi publicznej oraz wyposażenie w urządzenia infrastruktury technicznej spełniają wymogi realizacji obiektów budowlanych wynikające z odrębnych przepisów i aktów prawa miejscowego. Uregulowanie zawarte w $\S 12$ ust. 4 rozporządzenia Ministra Infrastruktury z 12 kwietnia 2002 r. w sprawie warunków technicznych, jakim powinny odpowiadać budynki i ich usytuowanie, nie będzie zatem miało zastosowania do realizacji budynku na działach rolnych, na których może być realizowana zabudowa zagrodowa.

Budynek jest tylko jednym z rodzajów obiektów budowlanych. Z art. 2 pkt 3 ustawy Prawo budowlane wynika, że budynek to taki obiekt budowlany, który jest trwale związany z gruntem, wydzielony z przestrzeni za pomocą przegród budowlanych oraz posiada fundamenty i dach. Uregulowanie zawarte $\mathrm{w} \S 12$ ust. $4 \mathrm{ww}$. rozporządzenia nie będzie miało zastosowania do innych obiektów budowlanych.

W odniesieniu do określonej grupy inwestycji wymagających uzyskania pozwolenia na budowę ustawodawca zrezygnował ze stosowania autonomicznej definicji strony postępowania. Zgodnie z treścią art. 28 ust. 4 ustawy Prawo budowlane

\footnotetext{
${ }^{5}$ Dz. U. 2015, poz. 1422 j.t.

${ }^{6}$ Dz. U. 2015, poz. 199 j.t. ze zm.
} 
art. 28 ust. 2 tej ustawy nie stosuje się $\mathrm{w}$ postępowaniu w sprawie pozwolenia na budowę wymagającym udziału społeczeństwa zgodnie z przepisami ustawy z 3 października 2008 r. o udostępnianiu informacji o środowisku i jego ochronie, udziale społeczeństwa $\mathrm{w}$ ochronie środowiska oraz o ocenach oddziaływania na środowisko ${ }^{7}$. Art. 79 ust. 1 tej ustawy stanowi, że przed wydaniem decyzji o środowiskowych uwarunkowaniach zgody na realizację inwestycji organ właściwy do jej wydania zapewnia możliwość udziału społeczeństwa w postępowaniu, w ramach którego przeprowadza ocenę oddziaływania przedsięwzięcia na środowisko. Przedsięwzięcia mogące znacząco oddziaływać na środowisko, których realizacja wymaga przeprowadzenia oceny oddziaływania na środowisko, wymienione zostały w art. 59 ust. 1 ww. ustawy z 3 października 2008 r. Rezygnacja ze stosowania $\mathrm{w}$ takich przypadkach $\mathrm{z}$ definicji strony zawartej w art. 28 ust. 2 ustawy Prawo budowlane oznacza, że zastosowanie będzie miała definicja zawarta w art. 28 k.p.a.

Autonomiczna definicja strony postępowania zawarta została też w art. 40 ust. 3 ustawy Prawo budowlane, który stanowi, że stronami w postępowaniu o przeniesienie decyzji o pozwoleniu na budowę lub o pozwoleniu na wznowienie robót budowlanych są jedynie podmioty, między którymi ma być dokonane przeniesienie decyzji. Podmiotami tymi będą z jednej strony osoby, które uzyskały pozwolenie na budowę lub wznowienie robót budowlanych, co wynikać będzie z treści pozwolenia, zaś z drugiej strony osoby, które są zainteresowane rozpoczęciem lub kontynuowaniem inwestycji na podstawie tego pozwolenia.

Rozwiązanie zawarte w art. 40 ust. 3 ustawy Prawo budowlane ma odpowiednie zastosowanie do sytuacji opisanych $\mathrm{w}$ art. 40 ust. 4 tej ustawy. $Z$ przepisu tego wynika, że prawa i obowiązki wynikające ze zgłoszenia, wobec którego organ nie wniósł sprzeciwu, mogą być przeniesione na rzecz innej osoby w drodze decyzji, a przepisy ust. 1 i 3 art. 40 stosuje się odpowiednio. Stronami tego postępowania będą osoby, które uzyskały możliwość realizacji inwestycji na podstawie zgłoszenia oraz osoby, które będą zainteresowane rozpoczęciem lub kontynuowaniem inwestycji w oparciu o dokonane zgłoszenie.

Ostatnia z autonomicznych definicji strony postępowania zawarta została w art. 59 ust. 7 ustawy Prawo budowlane. Przepis ten stanowi, że stroną w postępowaniu w sprawie pozwolenia na użytkowanie jest wyłącznie inwestor. Strona tego postępowania jest więc tożsama z pojęciem inwestora. Od zasady, że stroną postępowania w prawie uzyskania pozwolenia na użytkowanie jest ,wyłącznie inwestor", dopuścić należy wyjątki. Ma to miejsce wówczas, gdy inwestor nie chce wystąpić z wnioskiem o wydanie pozwolenia na użytkowanie lub wystapienie przez niego z takim wnioskiem nie jest możliwe.

Jak stwierdził Naczelny Sąd Administracyjny w wyroku z 16 maja 2013 r., sygn. akt II OSK $1695 / 12^{8}$, w sytuacji gdy deweloper - adresat pozwolenia na

\footnotetext{
${ }^{7}$ Dz. U. 2013, poz. 1232 j.t. ze zm.

${ }^{8} \mathrm{http}: / /$ orzeczenia.nsa.gov.pl
} 
budowę - odmawia wystapienia z wnioskiem o pozwolenie na użytkowanie, gdy budowa została już zakończona, a własność budynku przeszła na nabywcę, uniemożliwiając $\mathrm{w}$ ten sposób legalne zamieszkanie nowych właścicieli w takim budynku, ograniczenie podmiotowe z art. 59 ust. 7 ustawy Prawo budowlane nie może mieć zastosowania. Zdaniem Sądu prowadziłoby to bowiem do sytuacji, w której na skutek przyczyn leżących po stronie dewelopera, którego działania naruszają prawo, gdyż nie wywiązuje się on z ciążących na nim obowiązków, nie doszłoby do kontroli wybudowanego budynku pod względem zgodności z ustaleniami i warunkami określonymi w pozwoleniu na budowę, czego skutki poniósłby skarżący. Zdaniem NSA, deweloper nie może, jako inwestor, nadużywać swojej pozycji i nie dokonując czynności, do których zobowiązany jest z mocy przepisów prawa, wymuszać zaspokajania swoich roszczeń związanych z inwestycją. Takie zachowanie nie zasługuje na aprobatę.

Przytoczony wyżej pogląd należy w pełni podzielić. Ma on również zastosowanie w przypadku, gdy inwestor nie może wystapić z wnioskiem o wydanie pozwolenia na użytkowanie, gdyż przestał istnieć np. na skutek likwidacji.

Posługiwanie się przez ustawodawcę szczególnymi definicjami strony postępowania nie jest domena jedynie ustawy Prawo budowlane. Takie definicje zawarte są m.in. w ustawie z 18 lipca 2001 r. Prawo wodne9 (art. 127 ust. 7), w ustawie z 27 kwietnia 2001 r. Prawo ochrony środowiska ${ }^{10}$ (art. 185 ust. 1), w ustawie z 16 kwietnia 2004 r. o wyrobach budowlanych ${ }^{11}$ (art. 33 ust. 1). Tendencja do zawierania w aktach prawnych szczególnych definicji pojęcia „strona postępowania" będzie się zapewne nasilać. Ważne jest jednak przy tym, by nie prowadziło to do nieuzasadnionego pozbawiania obywateli prawa do ochrony uzasadnionych interesów poprzez udział w postępowaniu administracyjnym.

\section{BIBLIOGRAFIA}

Bieniek, Gerard, Stanisława Kalus, Zenon Marmaj, Eugeniusz Mzyk. 2005. Ustawa o gospodarce nieruchomościami. Komentarz. Warszawa: Wydawnictwo Prawnicze LexisNexis.

Dubisz, Stanisław. 2003. Uniwersalny słownik języka polskiego. Tom 4. Warszawa: Wydawnictwo Naukowe PWN.

Dźwiński, Robert, Paweł Ziemski. 2005. Prawo budowlane. Komentarz. Warszawa: Dom Wydawniczy ABC.

Radzikowski, Krzysztof. 2005. Glosa do wyroku Naczelnego Sqdu Administracyjnego z dnia 10 kwietnia 2001 roku, sygn. akt III SA 2996/99. Glosa 2005/3/118.

Siegień, Jerzy, Joanna Kubisiak. 2003. Prawo budowlane. Komentarz. Warszawa: Wydawnictwo C.H. Beck.

Uliasz, Marcin. 2002. „Czynności przekraczające zakres zwykłego zarządu, cz. I”. Monitor Praw. 18.

\footnotetext{
${ }^{9}$ Dz. U. 2015, poz. 469 j.t. ze zm.

${ }^{10}$ Dz. U 2013, poz. 1232 j.t. ze zm.

${ }^{11}$ Dz. U. 2014, poz. 883 j.t.
} 


\title{
Grzegorz Czerwiński
}

\section{A CONCEPT OF A PARTY TO PROCEEDINGS IN THE LIGHT OF PROVISIONS OF THE BUILDING LAW ACT OF 7 JULY 1994}

\begin{abstract}
The subject of the paper concerns legal problems related to a concept of a party to the proceedings in the light of provisions of the building law act of 7 July 1994. The issue which is analysed is of great theoretical and practical importance, especially in the process of applying provisions of the above regulation by courts and administrative offices. The aim of the considerations is also to present basic legal problems connected with interpretation of the concept of a party in a building trial in a practical aspect.
\end{abstract}

Keywords: building law, a party to the proceedings, building permit, definition, building trial. 